\title{
Fiber diameter, porosity and functional group gradients in electrospun scaffolds
}

Citation for published version (APA):

Zonderland, J., Rezzola, S., Wieringa, P., \& Moroni, L. (2020). Fiber diameter, porosity and functional group gradients in electrospun scaffolds. Biomedical Materials, 15(4), [045020]. https://doi.org/10.1088/1748-605X/ab7b3c

Document status and date:

Published: 01/07/2020

DOI:

10.1088/1748-605X/ab7b3c

Document Version:

Publisher's PDF, also known as Version of record

Document license:

Taverne

Please check the document version of this publication:

- A submitted manuscript is the version of the article upon submission and before peer-review. There can be important differences between the submitted version and the official published version of record.

People interested in the research are advised to contact the author for the final version of the publication, or visit the DOI to the publisher's website.

- The final author version and the galley proof are versions of the publication after peer review.

- The final published version features the final layout of the paper including the volume, issue and page numbers.

Link to publication

\footnotetext{
General rights rights.

- You may freely distribute the URL identifying the publication in the public portal. please follow below link for the End User Agreement:

www.umlib.nl/taverne-license

Take down policy

If you believe that this document breaches copyright please contact us at:

repository@maastrichtuniversity.nl

providing details and we will investigate your claim.
}

Copyright and moral rights for the publications made accessible in the public portal are retained by the authors and/or other copyright owners and it is a condition of accessing publications that users recognise and abide by the legal requirements associated with these

- Users may download and print one copy of any publication from the public portal for the purpose of private study or research.

- You may not further distribute the material or use it for any profit-making activity or commercial gain

If the publication is distributed under the terms of Article $25 \mathrm{fa}$ of the Dutch Copyright Act, indicated by the "Taverne" license above, 


\title{
Biomedical Materials
}

\section{PAPER}

CrossMark

RECEIVED

19 February 2020

REVISED

20 February 2020

ACCEPTED FOR PUBLICATION

28 February 2020

PUBLISHED

24 June 2020

\section{Fiber diameter, porosity and functional group gradients in electrospun scaffolds}

\author{
Jip Zonderland, Silvia Rezzola, Paul Wieringa $\left[\right.$ and Lorenzo Moroni ${ }^{1}$ (C) \\ Complex Tissue Regeneration Department, MERLN Institute for Technology-Inspired Regenerative Medicine, \\ Maastricht University, Maastricht, The Netherlands \\ 1 Author to whom any correspondence should be addressed. \\ E-mail:1.moroni@maastrichtuniversity.nl \\ Keywords: electrospinning, gradients, functional groups, fiber diameter, collector voltage \\ Supplementary material for this article is available online
}

\begin{abstract}
Developing, homeostatic, and regenerating tissues are full of various gradients, including mechanical, chemical, porosity and growth-factor gradients. However, it remains challenging to replicate these gradients using common tissue engineering approaches. Here, we use electrospinning to create scaffolds with in-depth gradients. We created a fiber diameter gradient and pore size gradient throughout the depth of electrospun (ESP) scaffolds by a continuous gradient of polymer concentration. As an alternative to this established method, we developed a novel method to create fiber diameter gradients by changing the voltage on both needle and collector, keeping the total voltage constant. In this way, fiber diameter could be changed in a gradient matter by focusing the electrospinning spot. Using this method, we created a fiber diameter and pore size gradient, while keeping all other parameters constant. Lastly, we developed a novel method to create functional group gradients, which can potentially be used in a wide variety of polymer solutions to couple peptides and proteins to ESP scaffolds. A scaffold with an in-depth gradient of functional groups was created by adding functionalized poly(ethylene glycol) additives to the polymer solution, a novel method with potentially wide applications. The techniques demonstrated here could be applied to a wide variety of polymers and applications and can aid in developing physiologically relevant gradient scaffolds.
\end{abstract}

\section{Introduction}

Embryonic and tissue development is steered largely through gradients [1-3]. In adult tissues, gradients are still present in, for example: cell distribution, extra-cellular matrix (ECM) proteins, physical properties and growth factors [4-8]. Regenerating tissues also use gradients in ECM remodeling and excreted growth factors [9-12]. The manufacturing of scaffolds with physiological properties has been the interest of tissue engineering researchers for the past decades. Mimicking these physiological gradient properties for tissue engineering could greatly benefit tissue function and regeneration. The creation of a wide variety of synthetic materials and isolation and characterization of biological materials allows researchers to pick materials that match the desired material properties. Also, many different proteins, peptides and minerals have been added to these materials to steer cell behavior. However, incorporating gradients in tissue engineering constructs remains challenging.

Several properties of a cell's surrounding has been shown to greatly influence cell behavior. Mechanical properties are an important factor of the cellular surroundings $[13,14]$. Proliferation, differentiation, ECM production and migration have all been shown to change in response to substrate stiffness. Many different cell types have been shown to proliferate more on stiffer substrates [15-22]. Mesenchymal stromal cells are more inclined to differentiate to bone on stiffer substrates, and more likely to commit to the adipose lineage on softer substrates $[16,23,24]$. However, these material properties are mostly exploited without gradients, while developing homeostatic and regenerating tissues consist of a wide variety of gradients [1-12]. To better recapitulate the 


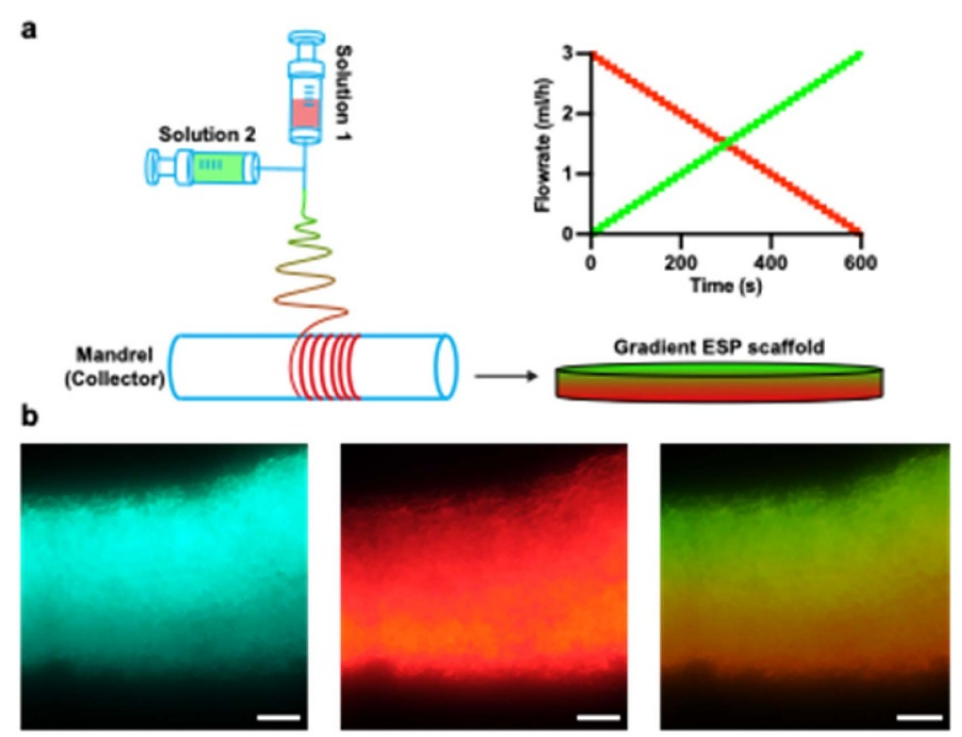

Figure 1. In-depth gradient in ESP scaffolds. (a) Schematic overview of electrospinning set up. Two syringes, one loaded with 300PEOT55PBT45 polymer solution and a green dye, the other with 300PEOT55PBT45 and a red dye. The solutions of each syringe flowed into a single tubing. The flowrates of each syringe were changed over time, increasing one while decreasing the other, keeping the total flow rate at $3 \mathrm{ml} \mathrm{h}^{-1}$. (b) Representative images of the cross-section of a scaffold with a high-low gradient of green dye (left) and a low-high gradient of red dye (middle). The right panel shows the merge of the green and red channel. Scalebars $250 \mu \mathrm{m}$.

tissue, tissue engineering scaffolds can potentially be greatly improved by incorporating gradients.

Gradients in stiffness guide cell migration in a process called durotaxis, where cells move to stiffer substrates [25-27]. Indeed, electrospun (ESP) scaffolds with an in-depth stiffness gradient have been shown to improve cellular infiltration in the scaffolds [28]. Pore size is another important aspect of the extra-cellular environment. Optimal pore size for differentiation and proliferation differs per cell type [29]. Additive manufactured scaffolds with a gradient in pore size have also been shown to influence cartilage matrix deposition and bone regeneration [30, 31]. Pore shape can also affect cell behavior, shape and orientation [32, 33]. Growth factors and adhesion molecules also play an important role in controlling cell behavior. Isotropic growth factor coupling is used in the tissue engineering field [34,35], but the use of gradients to mimic the physiological conditions is underexplored due to technical difficulties to create gradients. Several established methods to create horizontal (side to side) fiber diameter and protein gradients have been developed [36-40]. In addition, in-depth fiber diameter gradients have been developed by changing polymer concentration [28]. Here, we developed a novel method to create in-depth fiber diameter gradients using a gradual change in voltage. A univocal method to create in-depth protein gradients has not yet been described. We introduce a method to create in-depth functional group gradients by the addition of functionalized poly(ethylene glycol) (PEG) that could be used to create multi-directional protein or peptide gradients in a wide variety of polymers.

\section{Results}

\subsection{Creating bi-directional gradients in-depth of ESP scaffolds}

It remains challenging to replicate the gradients found in vivo in tissue engineering scaffolds. Layer by layer approaches have been reported in ESP scaffolds [41], but true in-depth gradients have not been widely reported in literature. An easy approach to create gradients in ESP scaffolds is using two syringe pumps with different solutions that feed into a single spinneret. As a proof of principle, we loaded one syringe with 300PEOT55PBT45 polymer solution and a green dye, and another with the polymer solution and a red dye. Over time, the flowrate of the first syringe was decreased, while the flowrate of the second syringe was increased, keeping the total flowrate equal (figure 1(a)). As expected, the green dye decreased in intensity over time, while the intensity of the red dye increased (figure 1(b)). Using this method, we created a scaffold with bi-directional gradients: high-low concentration of green dye, and a low-high concentration of red dye.

\subsection{Fiber diameter and porosity gradient by changing polymer concentration over time}

Adult tissues, such as cartilage and bone, are known to have a gradient in porosity [8, 42]. Mimicking such a gradient could potentially aid in capturing tissue properties and steering cell behavior. In ESP scaffolds, the fiber size and the pore size are inherently linked [43-50]. We have previously shown that increasing the polymer concentration from $20 \%$ (w/v) 300PEOT55PBT45 to 35\% results in an increase in fiber diameter and pore size, in line with reports for other polymers $[43,46,49]$. Thus, to create a fiber 


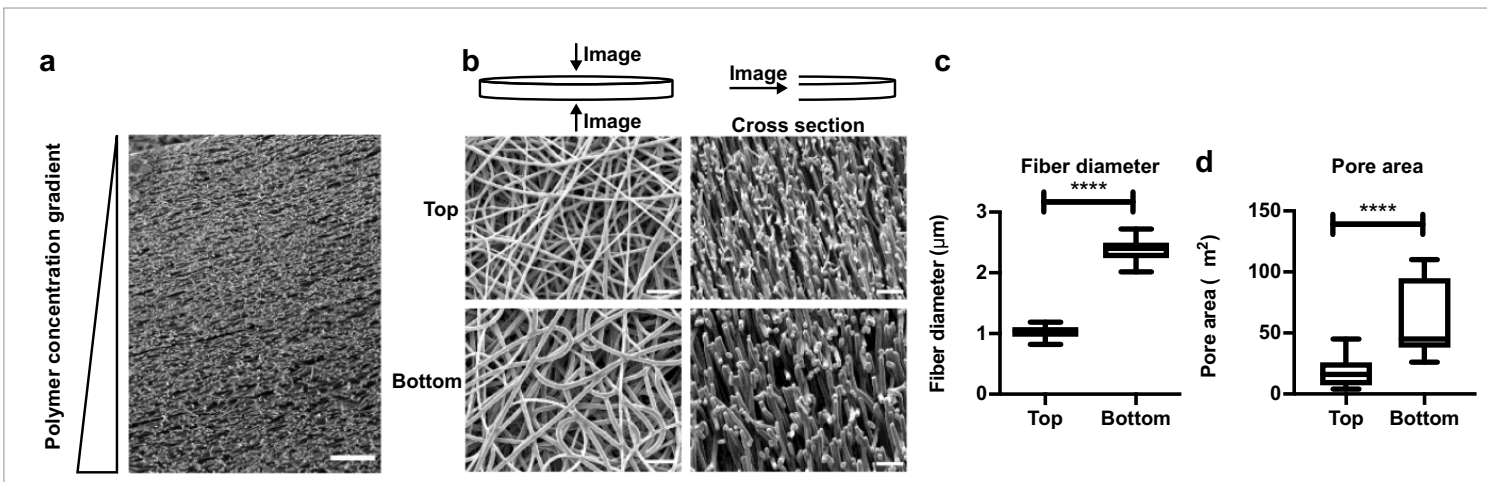

Figure 2. In-depth fiber diameter gradient. (a) Cross-section overview of fiber diameter gradient, made by changing the polymer concentration over time with the two syringe set-up. Scalebar $80 \mu \mathrm{m}$. (b) Top view (left panels) and cross-section (right panels) of the bottom and top of the fiber diameter gradient scaffold. Scalebars $15 \mu \mathrm{m}$. (c) - (d) Quantification of fiber diameter ( $\mathrm{n}=10-20)$ (c) and pore area $(\mathrm{n}=15)(\mathrm{d})$ of top and bottom of fiber diameter gradient scaffold. (c) Student's t-test. (d) Mann-Whitney test $* * * * \mathrm{p}<0.0001$.

diameter and porosity gradient in an ESP scaffold, we increased the polymer concentration from $20 \%$ to $35 \%$ over the time of spinning. Using the double syringe pump setup, ESP scaffolds with a gradient in fiber diameter were produced (figure 2(a)). At the bottom, where a 35\% (w/v) 300PEOT55PBT45 polymer solution was spun, $2.4 \pm 0.2 \mu$ m fibers were formed. By reducing the flowrate of the syringe containing 35\% 300PEOT55PBT45 and increasing the flowrate of the $20 \% 300$ PEOT55PBT45 containing syringe, an in-depth gradient in fiber diameter was created. At the top, where a $20 \%(\mathrm{w} / \mathrm{v})$ 300PEOT55PBT45 polymer solution was spun, fibers of $1.0 \pm 0.1 \mu \mathrm{m}$ were formed (figures 2(b) and (c)). The pore area on the bottom, with larger fiber diameter, also increased significantly $(\mathrm{p}<0.0001)$, compared to the top, with smaller fiber diameter. This demonstrates that a gradient in fiber diameter and pore size could be created by decreasing the polymer concentration over time.

\subsection{Fiber diameter and porosity gradient by changing voltage over time}

As an alternative method to modulate fiber diameter, we attempted to focus or scatter the electrospinning spot. We hypothesized that by focusing the spot size, fibers would have less time to stretch, thereby increasing the fiber diameter. Inversely, by increasing the spot size we could stretch fibers more and decrease the fiber diameter. We hypothesized that by decreasing the voltage of the collector and the needle, we could focus the spinning spot. Indeed, by setting the collector voltage to $-16 \mathrm{kV}$ and the needle to $4 \mathrm{kV}$, the spinning spot size decreased to $32.5 \pm 2.3 \mathrm{~cm}^{2}$ (figure $3(\mathrm{a})$ ). By setting the collector to $0 \mathrm{kV}$ and the needle to $20 \mathrm{kV}$, we increased the spot size $4.8 \mathrm{x}$ to $156.6 \pm 9.7 \mathrm{~cm}^{2}$. Together with the change in spot size, a change in fiber diameter was observed. In the $-16 \mathrm{kV}$ charged collector condition, a scaffold with $3.2 \pm 0.6 \mu \mathrm{m}$ fibers was obtained (figure $3(\mathrm{~b})$ ). When the collector was left uncharged, a scaffold with $2.1 \pm 0.4 \mu \mathrm{m}$ fibers was produced. Together with fiber diameter, the pore size also increased (figures 3(c) and (d)). To create a gradient in fiber diameter throughout the ESP scaffold, we gradually increased both needle and collector voltage (figure 3(f)). Indeed, a scaffold with in-depth fiber diameter gradient was produced (figures $3(\mathrm{e})-(\mathrm{g}))$. This is the first time a voltage gradient is used to create an in-depth gradient scaffold. This method is likely to work for a wide variety of polymer solutions and is easy to implement in many different electrospinning setups. The elegance of this approach is that all parameters, such as polymer concentration and flowrate, are kept constant, which could be used as a tool to specifically investigate the effect of just fiber diameter.

\subsection{Functional group gradient}

Besides mechanical and spatial cues, in vivo also many gradients of biological factors exist [9-11, 51-53]. To replicate this, we attempted to incorporate functional groups in the scaffold. Alkyne groups are a good candidate because they can be coupled very efficiently to an azide group by a copper-mediated click reaction. We have recently developed a method to present functional groups on the surface of ESP scaffolds by mixing low Mw PEG with a functional group in the polymer solution [54]. First, we tested whether different concentrations of PEG-alkyne added to the 300PEOT55PBT45 polymer solution would result in a different amount of alkyne groups at the surface of ESP scaffolds. After copper-mediated click reaction with a fluorescent azide dye, an increase in fluorescence was visible with increased PEG-Alk additive concentration (figure $4(\mathrm{a})$ ). Even at $0.001 \%(\mathrm{w} / \mathrm{v})$ slightly fluorescent fibers could be observed. The signal seemed to plateau around $1 \%$. We also tested other functional groups: PEG-SH (supplementary figure 1(stacks.iop.org/BMM/15/045020/mmedia)) and PEG- $\mathrm{NH}_{2}$ (supplementary figure 2) additives, which also increased the amount of available functional groups with increased concentration. To create a scaffold with an in-depth gradient of PEG-Alk, we loaded one syringe with 300PEOT55PBT45 +2\% 

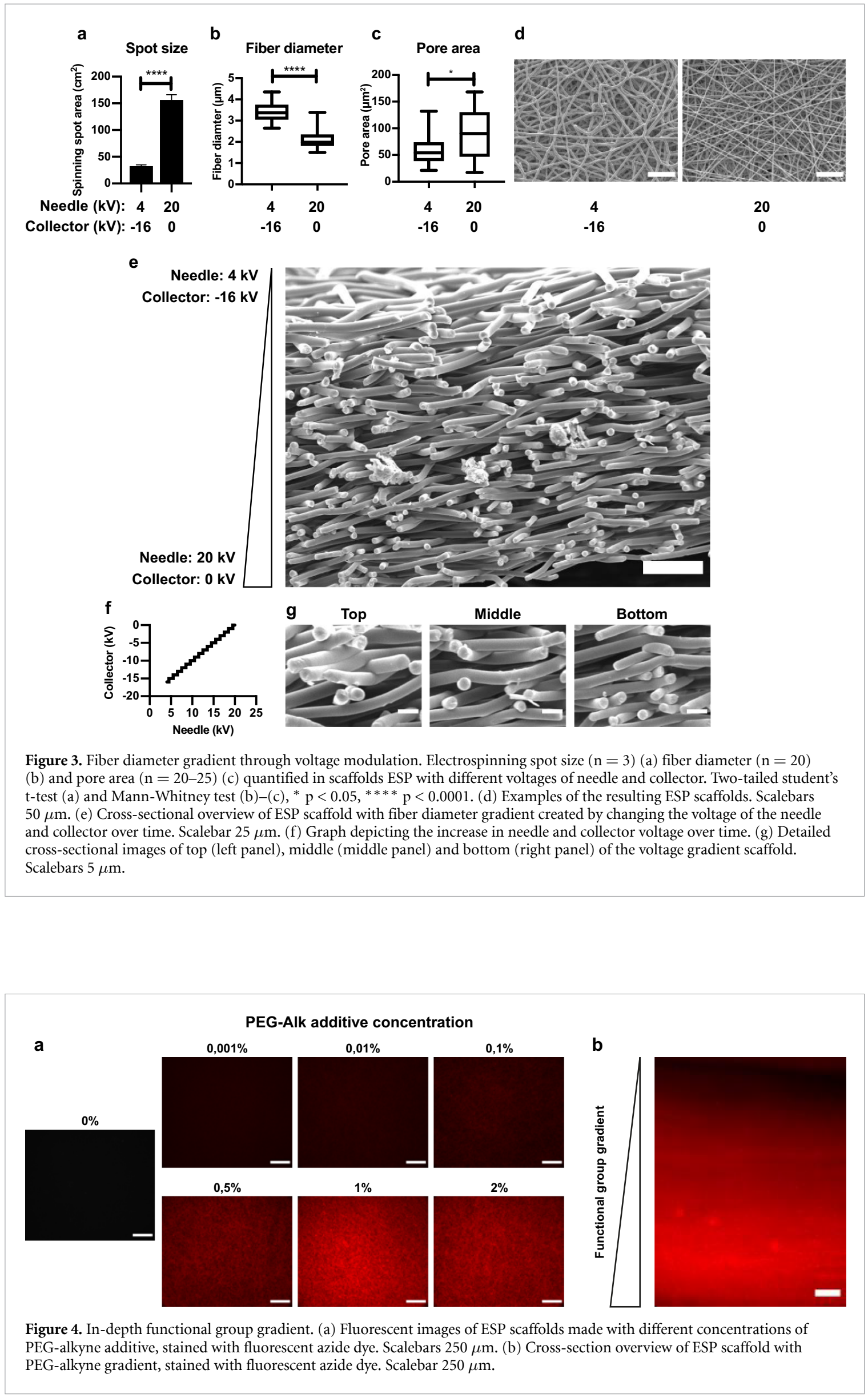
PEG-Alk and the other one with 300PEOT55PBT45 alone. The flowrate of the first syringe was gradually decreased while the flowrate of the second syringe increased. After coupling the fluorescent azide dye, the in-depth alkyne functional group gradient was visualized (figure $4(\mathrm{~b})$ ). These experiments showed that it is possible to present different functional groups in a gradient matter on the surface of ESP fibers by adding the PEG-additives. These PEGadditives can potentially be mixed with a wide variety of polymer solutions.

\section{Discussion}

We have used established technology and developed a new method to create in-depth gradients of fiber diameter and porosity in ESP scaffolds. A 300PEOT55PBT45 scaffold with a fiber diameter gradient going from $1 \mu \mathrm{m}$ to approximately $2.4 \mu \mathrm{m}$ was created by changing polymer concentration. Changing polymer concentration over the spinning time to create in-depth fiber diameter gradients has been reported previously $[28,55,56]$. Here, we have developed a novel method to create fiber diameter gradients. By gradually changing the needle and collector voltage over time, the electrospinning spot was focused and a gradient in fiber diameter was created from $2.1 \mu \mathrm{m}$ to $3.2 \mu \mathrm{m}$. Changing the fiber diameter by using a change in voltage over time has not yet been reported. The benefit of this novel method is that fiber diameter can be changed without changing other parameters, such as polymer concentration, allowing for the decoupling of different variables. In addition, this method could be combined with other methods, such as changing polymer concentration, to further increase or decrease the fiber diameter. Pore size has been optimized with a variety of methods, including a change in fiber diameter, but also incorporating sacrificial polymers or salt- or ice crystals [57-65]. Such methods could also be used in addition to the methods described here to further optimize pore size gradients.

In addition to the methods to create fiber diameter gradients, we created functional group gradients by adding functionalized PEG molecules to the polymer solution. While in-depth gradient of fiber diameter and pore size have been developed, as described above, in-depth functional group gradients in ESP scaffolds have not yet been reported. Methods to create functional group or protein gradients in the horizontal (side to side) direction have been developed [37, 38, 40], but these methods cannot be directly transferred to create in-depth functional group gradients. Here, we have developed a method to create in-depth functional group gradients that can potentially be used in a wide variety of polymer solutions. We have shown that different functional groups can easily be incorporated, including alkyne, thiol and amine groups. By coupling proteins or peptides to these functional groups, this method could be used to create multi-directional gradients for a wide variety of applications. An in-depth adhesive ligand gradient has been previously described [28], but the benefit of our method is that it could be univocally applied to a wide variety of proteins and peptides.

Together, these methods could be combined or used alone to create novel ESP gradient scaffolds. As regenerating tissues contain multiple forms of gradients, these scaffolds could potentially aid tissue engineering constructs for a wide variety of tissue engineering approaches. Regenerating or homeostatic tissues with gradients include: nerve, heart, skin, bone and cartilage, among others [4-12, 66].

On top of the tissue-recapitulation capacity of gradient scaffolds, these scaffolds can also be used for optimizations, having a single scaffold to test a wide range of a single variable [31, 67].

Most cellular responses to gradients have been studied in 2D. A better understanding of how gradients affect cell behavior in $3 \mathrm{D}$ could also lead to smarter design of tissue engineering scaffolds. Both the voltage gradient method and the functionalized PEG method developed here are well suited for these kind of studies, because fiber diameter or protein incorporation can be changed while keeping other parameters equal.

\section{Conclusion}

In summary, we have created in-depth gradients of fiber diameter, porosity and functional groups in ESP scaffolds. We have created a 300PEOT45PBT55 scaffold with a fiber diameter and pore size gradient using a change in polymer concentration, or a change in voltage. Also, we presented an easy way to create functional group gradients in a potentially wide range of polymer solutions, using PEG-alkyne, -thiol or amine additives. By changing the functional group on the PEG additive, a wide variety of functional groups can be presented in gradients on ESP scaffolds. Together, the methods presented here could be used to create more physiologically relevant scaffolds with continuous physical and chemical gradients.

\section{Methods}

\subsection{Electrospinning}

300PEOT55PBT45 is a segmented block co-polymer of $300 \mathrm{Da}$ poly(ethelyne oxide terephthalate) and poly(butylene terephthalate) with a PEOT/PBT weight ratio of $55 / 45$ (PolyVation). $20 \%$ or $35 \%$ $(\mathrm{w} / \mathrm{v})$ 300PEOT55PBT45 was dissolved overnight under agitation at room temperature in a mixture of 70\% Chloroform (Sigma-Aldrich) and 30\% 1,1,1,3,3,3-Hexafluoro-2-propanol AR (HFIP) (BioSolve). Electrospinning was done using the Bioinicia Fluidnatek LE-100. For the dye and PEG additive experiments, a $20 \%$ polymer solution was used. For 
the fiber diameter gradient scaffolds, $20 \%$ and $35 \%$ 300 PEOT55PBT 45 were used. For the voltage gradient experiments, 35\% 300PEOT45PBT was used. ESP scaffolds were produced on a $19 \mathrm{~cm}$ diameter mandrel rotating at $100 \mathrm{RPM}$ to produce a large batch of scaffolds at the same time under exactly the same conditions. The following conditions were maintained: $15 \mathrm{~cm}$ working distance, $3 \mathrm{ml} \mathrm{h}^{-1}$ flow rate, $23^{\circ} \mathrm{C}-25^{\circ} \mathrm{C}$ and $40 \%$ humidity. For the dye, polymer concentration and PEG additive experiments, the mandrel was uncharged and the needle was charged between 20 and $25 \mathrm{kV}$. For the voltage gradient scaffolds, the mandrel voltage was varied (see voltage gradient section). ESP scaffolds were collected on aluminum foil

\subsection{Flowrate gradient}

In-depth gradients were created by increasing the flowrate of one syringe while decreasing the flowrate of the second syringe. To control the flowrate, a custom LabVIEW program was developed (supplementary figures 3 and 4 ). The two syringes were connected in a $90^{\circ}$ angle, with $1 \mathrm{~m}$ tubing after the connection point to ensure sufficient mixing of the two solutions. For the proof of concept experiment with fluorescent dyes, we mixed Macrolex fluorescent yellow $10 \mathrm{G}$ (Lanxess) and Macrolex fluorescent red G (Lanxess) at $1 \mathrm{mg} \mathrm{ml}^{-1}$ with the $20 \% 300$ PEOT45PBT polymer solution for $4 \mathrm{~h}$. The gradient was produced by changing the flowrates from $0-3$ or $3-0 \mathrm{ml} \mathrm{h}^{-1}$ in 30 steps, over the course of $5 \mathrm{~min}$. The polymer concentration gradient and PEG-Alk gradient were produced by changing flowrates in 40 steps over $10 \mathrm{~min}$. The PEG-Alk, PEG-SH and PEG-NH $\mathrm{NH}_{2}$ (Sigma-Aldrich) were all mixed for $4 \mathrm{~h}$ before electrospinning. All PEG chains were $5000 \mathrm{Da}$ with both ends functionalized.

The PEG-Alk scaffolds were stained with $10 \mu \mathrm{g} \mathrm{ml}^{-1}$ azide Megastokes 673 (Sigma-Aldrich) in $2.5 \mathrm{~mm}$ copper sulfate (Sigma-Aldrich) and $25 \mathrm{~mm}$ sodium ascorbate (Sigma-Aldrich) in water overnight at room temperature. The PEG-SH scaffolds were stained with $10 \mu \mathrm{g} \mathrm{ml}{ }^{-1}$ DyLight-488 (Thermo Fisher) overnight in PBS at room temperature. The PEG-NH $\mathrm{N}_{2}$ scaffolds were stained with $30 \mu \mathrm{g} \mathrm{ml}-1$ fluorescamine (Sigma-Aldrich) in $10 \%$ acetone and $90 \%$ water for $5 \mathrm{~min}$. After staining of each PEGadditive scaffold, scaffolds were washed $3 \mathrm{x}$ with water and imaged under the fluorescent microscope, or in the case of PEG-NH $\mathrm{H}_{2}$, quantified using the CLARIOstar $^{\text {TM }}$ platereader (BMG Labtech).

\subsection{Voltage gradient}

In-depth fiber diameter gradients were created by changing the voltage of both needle and collector. To control the voltage, a custom LabVIEW program was developed (supplementary figures 5 and 6). In 17 steps ( $1 \mathrm{kV} / \mathrm{step}$ ) over the course of $4 \mathrm{~min}$, the voltage was changed from $4 \mathrm{kV}$ on the needle and $-16 \mathrm{kV}$ on the mandrel to $20 \mathrm{kV}$ and $0 \mathrm{kV}$, respectively.

\subsection{Fiber and pore size quantification}

Fiber diameter and pore area were quantified manually using a custom-built Fiji script. At least three different images of at least two different scaffolds were taken and around 20 fibers or pores were measured. To quantify pore area, images were acquired with high contrast to create a dark background within pores that were deeper than a few fiber layers. The pore area of these pores on the surface of the scaffolds were measured in the biggest pores in each image.

\subsection{Statistical analysis}

All data was tested for normal distribution using the Shapiro-Wilk test. Two-tailed student's t-test was performed for normally distributed samples and the Mann-Whitney test was used as non-parametric equivalent. Fiber diameter analysis was done using a custom-made macro in Fiji, while pore size was manually measured in the top layer of fibers, analyzing at least 20 fibers in three separate images.

\section{Acknowledgments}

We are grateful to the European Research Council starting grant 'Cell Hybridge' for financial support under the Horizon2020 framework program (Grant No. 637308).

\section{ORCID iDs}

Paul Wieringa

(1) https://orcid.org/0000-0002-3290-5125

Lorenzo Moroni

(1) https://orcid.org/0000-0003-1298-6025

\section{References}

[1] Gurdon J B and Bourillot P Y 2001 Morphogen gradient interpretation Nature 413 797-803

[2] Christian J L 2012 Morphogen gradients in development: from form to function Wiley Interdiscip. Rev. Dev. Biol. $13-15$

[3] Briscoe J and Small S 2015 Morphogen rules: design principles of gradient-mediated embryo patterning Development 142 3996-4009

[4] Parent C A and Devreotes P N 1999 A cell's sense of direction Science 284 765-70

[5] Di Luca A, Van Blitterswijk C and Moroni L 2015 The osteochondral interface as a gradient tissue: from development to the fabrication of gradient scaffolds for regenerative medicine Birth Defects Res., Part C 105 34-52

[6] Sophia Fox A J, Bedi A and Rodeo S A 2009 The basic science of articular cartilage: structure, composition, and function Sports Health 1 461-8

[7] Nieminen H J et al 2015 Determining collagen distribution in articular cartilage using contrast-enhanced micro-computed tomography Osteoarthr. Cartil. 23 1613-21

[8] Buck D W 2nd and Dumanian G A 2012 Bone biology and physiology: part I. The fundamentals Plast. Reconstr. Surg. 129 1314-20

[9] Eichmann A, Le Noble F, Autiero M and Carmeliet P 2005 Guidance of vascular and neural network formation Curr. Opin. Neurobiol. 15 108-15 
[10] Tessier-Lavigne M and Goodman C S 1996 The molecular biology of axon guidance Science 274 1123-33

[11] Goldman J, Conley K A, Raehl A, Bondy D M, Pytowski B, Swartz M A, Rutkowski J M, Jaroch D B and Ongstad E L 2007 Regulation of lymphatic capillary regeneration by interstitial flow in skin Am. J. Physiol. Heart Circ. Physiol. 292 H2176-83

[12] Xue M and Jackson C J 2015 Extracellular matrix reorganization during wound healing and its impact on abnormal scarring $A d v$. Wound Care 4 119-36

[13] Li S, Guan J L and Chien S 2005 Biochemistry and biomechanics of cell motility Annu. Rev. Biomed. Eng. 7 105-50

[14] Discher D E, Janmey P and Wang Y L 2005 Tissue cells feel and respond to the stiffness of their substrate Science 310 1139-43

[15] Wells R G 2008 The role of matrix stiffness in regulating cell behavior Hepatology 47 1394-400

[16] Sun M et al 2018 Effects of matrix stiffness on the morphology, adhesion, proliferation and osteogenic differentiation of mesenchymal stem cells Int. J. Med. Sci. 15 257-68

[17] Liu N, Zhou M, Zhang Q, Yong L, Zhang T, Tian T, Ma Q, Lin S, Zhu B and Cai X 2018 Effect of substrate stiffness on proliferation and differentiation of periodontal ligament stem cells Cell Prolif. 51 e12478

[18] Hui L, Zhang J, Ding X, Guo X and Jiang X 2017 Matrix stiffness regulates the proliferation, stemness and chemoresistance of laryngeal squamous cancer cells Int. J. Oncol. 50 1439-47

[19] Yeh Y T, Hur S S, Chang J, Wang K C, Chiu J J, Li Y S and Chien S 2012 Matrix stiffness regulates endothelial cell proliferation through septin 9 PLoS One 7 e46889

[20] Shkumatov A, Thompson M, Choi K M, Sicard D, Baek K, Kim D H, Tschumperlin D J, Prakash Y S and Kong H 2015 Matrix stiffness-modulated proliferation and secretory function of the airway smooth muscle cells Am. J. Physiol. Lung Cell Mol. Physiol. 308 L1125-35

[21] Razinia Z, Castagnino P, Xu T, Vazquez-Salgado A, Pure E and Assoian R K 2017 Stiffness-dependent motility and proliferation uncoupled by deletion of CD44 Sci. Rep. 716499

[22] Schrader J, Gordon-Walker T T, Aucott R L, van Deemter M, Quaas A, Walsh S, Benten D, Forbes S J, Wells R G and Iredale J P 2011 Matrix stiffness modulates proliferation, chemotherapeutic response, and dormancy in hepatocellular carcinoma cells Hepatology 53 1192-205

[23] Park J S, Chu J S, Tsou A D, Diop R, Tang Z, Wang A and Li S 2011 The effect of matrix stiffness on the differentiation of mesenchymal stem cells in response to TGF- $\beta$ Biomaterials 32 3921-30

[24] Lv H, Li L, Sun M, Zhang Y, Chen L, Rong Y and Li Y 2015 Mechanism of regulation of stem cell differentiation by matrix stiffness Stem. Cell Res. Ther. 6103

[25] Lo C M, Wang H B, Dembo M and Wang Y L 2000 Cell movement is guided by the rigidity of the substrate Biophys. J. 79 144-52

[26] Kidoaki S and Matsuda T 2008 Microelastic gradient gelatinous gels to induce cellular mechanotaxis J. Biotechnol. $133225-30$

[27] Gray D S, Tien J and Chen C S 2003 Repositioning of cells by mechanotaxis on surfaces with micropatterned Young's modulus J. Biomed. Mater. Res. A 66 605-14

[28] Sundararaghavan H G and Burdick J A 2011 Gradients with depth in electrospun fibrous scaffolds for directed cell behavior Biomacromolecules 12 2344-50

[29] Oh S H, Park I K, Kim J M and Lee J H 2007 in vitro and in vivo characteristics of PCL scaffolds with pore size gradient fabricated by a centrifugation method Biomaterials 28 1664-71

[30] Roy T D, Simon J L, Ricci J L, Rekow E D, Thompson V P and Parsons J R 2003 Performance of degradable composite bone repair products made via three-dimensional fabrication techniques J. Biomed. Mater. Res. A 66 283-91

[31] Woodfield T B, Van Blitterswijk C A, De Wijn J, Sims T J, Hollander A P and Riesle J 2005 Polymer scaffolds fabricated with pore-size gradients as a model for studying the zonal organization within tissue-engineered cartilage constructs Tissue Eng. 11 1297-311

[32] Zmora S, Glicklis R and Cohen S 2002 Tailoring the pore architecture in $3 \mathrm{D}$ alginate scaffolds by controlling the freezing regime during fabrication Biomaterials 23 4087-94

[33] Ma P X and Zhang R 2001 Microtubular architecture of biodegradable polymer scaffolds J. Biomed. Mater. Res. 56 469-77

[34] Chen R, Wang J and Liu C 2016 Biomaterials act as enhancers of growth factors in bone regeneration $A d v$. Funct. Mater. 26 8810-23

[35] Guex A G, Hegemann D, Giraud M N, Tevaearai H T, Popa A M, Rossi R M and Fortunato G 2014 Covalent immobilisation of VEGF on plasma-coated electrospun scaffolds for tissue engineering applications Colloids Surf. B $123724-33$

[36] Ramalingam M, Young M F, Thomas V, Sun L, Chow L C, Tison C K, Chatterjee K, Miles W C and Simon Jr C G 2013 Nanofiber scaffold gradients for interfacial tissue engineering J. Biomater. Appl. 27 695-705

[37] Shi J, Wang L, Zhang F, Li H, Lei L, Liu L and Chen Y 2010 Incorporating protein gradient into electrospun nanofibers as scaffolds for tissue engineering ACS Appl. Mater. Interfaces 2 1025-30

[38] Tanes M L, Xue J and Xia Y 2017 A general strategy for generating gradients of bioactive proteins on electrospun nanofiber mats by masking with bovine serum albumin J. Mater. Chem. B 5 5580-7

[39] Samavedi S, Olsen Horton C, Guelcher S A, Goldstein A S and Whittington A R 2011 Fabrication of a model continuously graded co-electrospun mesh for regeneration of the ligament-bone interface Acta Biomater. 7 4131-8

[40] Wu T, Xue J, Li H, Zhu C, Mo X and Xia Y 2018 General method for generating circular gradients of active proteins on nanofiber scaffolds sought for wound closure and related applications ACS Appl. Mater. Interfaces 10 8536-45

[41] Kim J S, Im B G, Jin G and Jang J H 2016 Tubing-electrospinning: a one-step process for fabricating fibrous matrices with spatial, chemical, and mechanical gradients ACS Appl. Mater. Interfaces 8 22721-31

[42] Bian W, Lian Q, Li D, Wang J, Zhang W, Jin Z and Qiu Y 2016 Morphological characteristics of cartilage-bone transitional structures in the human knee joint and CAD design of an osteochondral scaffold Biomed. Eng. OnLine 1582

[43] Pham Q P, Sharma U and Mikos A G 2006 Electrospun poly(epsilon-caprolactone) microfiber and multilayer nanofiber/microfiber scaffolds: characterization of scaffolds and measurement of cellular infiltration Biomacromolecules 7 2796-805

[44] Soliman S et al 2010 Multiscale three-dimensional scaffolds for soft tissue engineering via multimodal electrospinning Acta Biomater. 6 1227-37

[45] Lowery J L, Datta N and Rutledge G C 2010 Effect of fiber diameter, pore size and seeding method on growth of human dermal fibroblasts in electrospun poly(epsilon-caprolactone) fibrous mats Biomaterials 31 491-504

[46] Powell H M and Boyce S T 2008 Fiber density of electrospun gelatin scaffolds regulates morphogenesis of dermal-epidermal skin substitutes J. Biomed. Mater. Res. A 84 1078-86

[47] Sisson K, Zhang C, Farach-Carson M C, Chase D B and Rabolt J F 2010 Fiber diameters control osteoblastic cell migration and differentiation in electrospun gelatin $J$. Biomed. Mater. Res. A 94 1312-20

[48] Rnjak J, Li Z, Maitz P K, Wise S G and Weiss A S 2009 Primary human dermal fibroblast interactions with open weave three-dimensional scaffolds prepared from synthetic human elastin Biomaterials 30 6469-77 
[49] Balguid A, Mol A, van Marion M H, Bank R A, Bouten C V and Baaijens F P 2009 Tailoring fiber diameter in electrospun poly(epsilon-caprolactone) scaffolds for optimal cellular infiltration in cardiovascular tissue engineering Tissue Eng. Part A 15 437-44

[50] Eichhorn S J and Sampson W W 2005 Statistical geometry of pores and statistics of porous nanofibrous assemblies J. $R$. Soc. Interface 2 309-18

[51] Gerhardt H 2008 VEGF and endothelial guidance in angiogenic sprouting Organogenesis 4 241-6

[52] Greenhalgh D G 1996 The role of growth factors in wound healing J. Trauma 41 159-67

[53] Siwicka K A, Kitoh H, Kawasumi M and Ishiguro N 2011 Spatial and temporal distribution of growth factors receptors in the callus: implications for improvement of distraction osteogenesis Nagoya J. Med. Sci. 73 117-27

[54] Wieringa P, Girao A, Truckenmuller R, Welle A, Micera S, van Wezel R and Moroni L 2019 A one-step biofunctionalization strategy of electrospun scaffolds enables spatially selective presentation of biological cues (bioRxiv:https://doi.org/10.1101/850875)

[55] Grey C P, Newton S T, Bowlin G L, Haas T W and Simpson D G 2013 Gradient fiber electrospinning of layered scaffolds using controlled transitions in fiber diameter Biomaterials 34 4993-5006

[56] Timnak A, Gerstenhaber J A, Dong K, Har-El Y E and Lelkes P I 2018 Gradient porous fibrous scaffolds: a novel approach to improving cell penetration in electrospun scaffolds Biomed. Mater. 13065010

[57] Soliman S, Sant S, Nichol J W, Khabiry M, Traversa E and Khademhosseini A 2011 Controlling the porosity of fibrous scaffolds by modulating the fiber diameter and packing density J. Biomed. Mater. Res. A 96 566-74

[58] Ju Y M, Choi J S, Atala A, Yoo J J and Lee S J 2010 Bilayered scaffold for engineering cellularized blood vessels Biomaterials 31 4313-21
[59] Nam J, Huang Y, Agarwal S and Lannutti J 2007 Improved cellular infiltration in electrospun fiber via engineered porosity Tissue Eng. 13 2249-57

[60] Leong M F, Chan W Y, Chian K S, Rasheed M Z and Anderson J M 2010 Fabrication and in vitro and in vivo cell infiltration study of a bilayered cryogenic electrospun poly(D,L-lactide) scaffold J. Biomed. Mater. Res. A 94 1141-9

[61] Leong M F, Rasheed M Z, Lim T C and Chian K S 2009 In vitro cell infiltration and in vivo cell infiltration and vascularization in a fibrous, highly porous poly(D,L-lactide) scaffold fabricated by cryogenic electrospinning technique J. Biomed. Mater. Res. A 91 231-40

[62] Baker B M, Shah R P, Silverstein A M, Esterhai J L, Burdick J A and Mauck R L 2012 Sacrificial nanofibrous composites provide instruction without impediment and enable functional tissue formation Proc. Natl Acad. Sci. USA 109 14176-81

[63] Guimaraes A, Martins A, Pinho E D, Faria S, Reis R L and Neves N M 2010 Solving cell infiltration limitations of electrospun nanofiber meshes for tissue engineering applications Nanomed. (London) 5 539-54

[64] Voorneveld J, Oosthuysen A, Franz T, Zilla P and Bezuidenhout D 2017 Dual electrospinning with sacrificial fibers for engineered porosity and enhancement of tissue ingrowth J. Biomed. Mater. Res. B 105 1559-72

[65] Wang K, Xu M, Zhu M, Su H, Wang H, Kong D and Wang L 2013 Creation of macropores in electrospun silk fibroin scaffolds using sacrificial PEO-microparticles to enhance cellular infiltration J. Biomed. Mater. Res. A $1013474-81$

[66] Carruth E D, McCulloch A D and Omens J H 2016 Transmural gradients of myocardial structure and mechanics: implications for fiber stress and strain in pressure overload Prog. Biophys. Mol. Biol. 122 215-26

[67] Valmikinathan C M, Wang J, Smiriglio S, Golwala N G and Yu X 2009 Magnetically induced protein gradients on electrospun nanofibers Comb. Chem. High Throughput Screen. 12 656-63 